\title{
Analytical Competences of Teachers in Big Data in the Era of Digitalized Learning
}

\author{
Jesús López-Belmonte ${ }^{1, *(\mathbb{D})}$, Santiago Pozo-Sánchez ${ }^{2} \mathbb{D}$, Arturo Fuentes-Cabrera ${ }^{2} \mathbb{D}$ and \\ Juan-Manuel Trujillo-Torres 2 (D) \\ 1 International University of Valencia, 46002 Valencia, Spain \\ 2 Department of Didactics and School Organization, University of Granada, 18071 Granada, Spain \\ * Correspondence: jesus.lopezb@campusviu.es
}

Received: 15 June 2019; Accepted: 1 July 2019; Published: 10 July 2019

\begin{abstract}
The progress of technology in the field of education has led to the development of new professional skills in the teaching community, such as digital competence. Likewise, it has propagated the appearance of new learning environments mediated by technological resources that favor the generation of a large volume of data, known as Big Data, derived from the interactions of educational agents in virtual environments. This study aims to determine the level of digital competence in the informational area of teachers and to determine the projection of Big Data in them. For this study, a descriptive and correlational quantitative method was followed. The study sample consists of 832 Spanish teachers, with data collected through a questionnaire. The results reveal that the teaching staff have a medium level of digital competence in the informational area. The teachers obtained better valuations in the dimensions concerning storage and recovery, postulating themselves as connoisseurs of the Big Data concept to a large extent. In some instances, the teachers affirmed that sometimes they access and interpret the data generated by the digital interactions, transforming it into useful information to improve their teaching processes. Finally, our research shows that the level of digital competence in the informational area influences the degree of knowledge about Big Data.
\end{abstract}

Keywords: information and communication technologies (ICT); digital competence; big data; data management

\section{Introduction}

Due to the continuous advances produced in the digital era, in which we are all immersed, technology has reached a level that now impacts all areas of society, including the education sector. This technological evolution has had some positive consequences, considerably impacting the training processes of both teaching and learning [1]. Due to this, the education sector is currently in a phase of renewal, where the roles and praxis carried out by the main educational agents are being transformed, with a focus on new types of learning that can be enriched by technology [2].

For this innovative perspective to flourish, certain skills and knowledge in technological matters are required from both teachers and students. Having been born and raised in a society in constant transformation, students demonstrate a greater familiarization with the current electronic resources [3].

The inclusion of educational technology is motivated to respond to a student group that has been exposed to the digital revolution from an early age and to satisfy their needs and concerns [4]. This is one of the key reasons that the use of a teaching practice that has been adapted to the new educational paradigms is required [5]. All this is reflected in the current legislation on education (Organic Law 8/2013, of December 9, for the improvement of educational quality) [6], which states that information and communication technologies (henceforth ICT) must be used for pedagogical purposes in the 
various areas that make up the curriculum, with the purpose of promoting the inclusion of resources and digital tools that stimulate different activities amongst both teachers and students [7].

From a pedagogical approach, the broad development of ICT has led to the realization of innovative learning experiences, focused on the learner as the main active agent and promoter of their knowledge [8]. This moves the teacher away from a role in direct communication of knowledge, to that of a professional in charge of managing the different innovative means to improve educational processes and adapt learning to the singularities of students [9].

The use of educational technology reports a series of benefits that have been verified in the scientific literature by different researchers and experts in this field. Their findings show that the use of technological advancements in teaching entails the promotion and improvement of meaningful learning [10], constructivist approaches [11], effectiveness of learning [12] and, consequently, a greater increase in student motivation [13]. For these reasons, following Kumar and Kumar [14], the incorporation of technological innovations in the educational field is fundamental.

\subsection{The Digital Competence of the Teaching Staff: An Indispensable Professional Faculty}

To achieve the desired level of ICT in an educational setting, it is necessary that teachers have a sufficient level of digital competence. This need to develop an entirely new skill set is one of the main concerns of current teachers [15], as it will require continuous training in order to increase and improve the skills and abilities linked to a techno-pedagogical treatment of available resources [16].

For a better terminological understanding, Castaneda et al. [17] and Lazaro et al. [18] consider that the concept of digital competence brings together all the knowledge and skills that teachers gather to effectively achieve management and deployment of technology in the educational field. In the same way, Avitia and Uriarte [19] postulate that this is not a static term, given that technology is constantly changing and, consequently, the level of knowledge is also altered if continuous training is not established to maintain or increase it.

In Spain, at the state level, the organization responsible for regulating digital teaching competence is the National Institute of Educational Technologies and Teacher Training (INTEF, in Spanish). This entity has classified digital competence into five broad areas, which are information and information literacy (A1), communication and collaboration (A2), the creation of digital content (A3), security (A4) and problem solving (A5) [20].

Although technology occupies a privileged place among current educational policies, recently published studies, such as those developed by Fernández et al. [21], Fernández and Rodríguez [22] and Fuentes et al. [23] show that teachers do not have the necessary digital competencies to carry out a professional exercise. This lack of digital competence is having a direct impact on their ability to engage with techno-pedagogical resources and innovative tools [24].

This lack of training directly affects the development and inclusion of digital teaching methods, as teachers cannot take advantage of the potential benefits that the use of new media developed for teaching can create [25]. In the same way, previous investigations have studied the causes of such low digital competence amongst teachers, determining that they are due to a deficient attitude prior to the adoption of new ways of teaching and learning [26,27], a reluctance to engage with pedagogical transformation [28], and gaps detected in the management of electronic resources [29]. All of these factors, in the opinions of Afanador [30], Falco [31], Fernández and Fernández [32] and Fernández, et al. [33], directly affect professional competences, causing a low level of digital skills in teaching staff.

This derives from the principle of isomorphism, which establishes that older teachers with less technological training at a complementary level have greater problems in carrying out a professional exercise through a techno-pedagogical approach [34].

Therefore, digital competence is established as a fundamental quality in today's teachers. [35], In order to reduce the knowledge gap that has originated between teacher and learner, as Cabero and Ruiz [36] postulated, knowledge and learning of digital methods is required that responds to the 
needs of a generation of students born into a society conditioned by constant access to information, knowledge, and learning [37].

\subsection{Digital Learning and Massive Data Generation}

As a result of the progress that technology has experienced, an educational approach called mobile learning [38] has emerged that has had a great impact in recent years [39]. It is a very formative modality, studied in the scientific literature [40] for its advantages in teaching and learning processes [41] and for the interest of teachers to carry out their vocation from daily technological resources which are increasingly sophisticated and that principally present a social nature [42]. Likewise, mobile learning has managed to increase the motivation, performance and collaboration of the students in digital environments [43]. This new approach focuses on the mobility and ubiquity of the training act, carried out through virtual platforms and mobile devices [44,45], that report an immense amount of data originated from the interactions and actions of students in the digital space [46,47].

This set of data—generated in different digital spaces and web services—is known as Big Data [48]. At present, this concept is being treated in the specialized literature as a consequence of the great impact and interaction of people in digital media, resulting in a huge volume of data [49], which gave rise to a second digital era, that of the Big Data [50].

This virtual construct is mainly promoted by the great connectivity that technology has brought to society [51], in which each person's action is recorded [52], and can be studied through specific programs that present a great capacity to process and analyze complex databases [53]. The interest to investigate this type of data lies in knowing the demands of the users [54] and, by consequence, making the right decisions to effectively meet the needs of the people [49].

Big Data has been extended by diverse fields, education being one of them [55] in which numerous data coming from the processes of teaching and learning are being compiled [56], giving rise to teaching development based on the treatment and study of the data generated by the learning activity [57]. All of this is focused on the improvement of educational quality in virtual media [58] and the adaptation of student singularities [59].

By conducting a deep analysis of Big Data, a contribution can be made to the improvement of educational experiences that meet the requirements of innovative education, allowing a selection of didactic strategies and effective decision-making based on the analyzed data [60,61].

An important aspect is that the management of Big Data requires certain skills in analytical treatment based on data mining, for the extraction of useful, valuable and meaningful information from Big Data [62].

Consequently, information competence as part of the digital competence of teachers acquires great relevance in the information society [63], to have strategies analogous to search, selection, evaluation [64] and the use of data [65], through critical thinking that allows the generation of new information that is relevant to the learning process [66].

In this sense, information competence brings together skills such as navigation, search, access, filtering, management, storage, organization, processing, recovery, analysis, evaluation, comparison and interpretation of data [67].

Experts such as Menon, Gaglani, Haynes and Tackett [68] show that the treatment that teachers give Big Data does not reach efficiency due to the lack of training in data analytics. In the same vein, Álvarez and Gisbert [69] specify that teachers have a shortfall of competence in the management, evaluation and transformation of data in information.

Therefore, teaching practice in the use and analysis of Big Data is presented as one of the great challenges to solve the gaps found in education, in order to achieve greater productivity, efficiency and personalization of the learning process, appropriate to the characteristics of the students through the extraction and understanding of relevant information after an in-depth analysis of educational data [70]. 


\subsection{Justification and Objectives of the Study}

Owing to the prosperity and development of educational technology and the proliferation of data from educational platforms and educational resources, it is of interest to investigate the informational competency of teachers to achieve effective practices in the treatment of Big Data, leading to pertinent management and analysis of ample volumes of data with the purpose of generating relevant and useful information to improve the quality of the training processes.

Although the concept of Big Data refers to the treatment of a huge amount of data from various sources and computer records, this work has taken one of the perspectives of this term, focusing attention on the management and analysis of teachers in the educational data generated in the platforms used to carry out the training action digitally.

It is essential that teachers make pedagogical use of technology in order to fully integrate ICT in education. This will only be achieved if the teaching group benefits from all the potential offered by technology from an educational perspective.

This study differs from previous ones in terms of the connections that are established between the concepts shown in Figure 1.

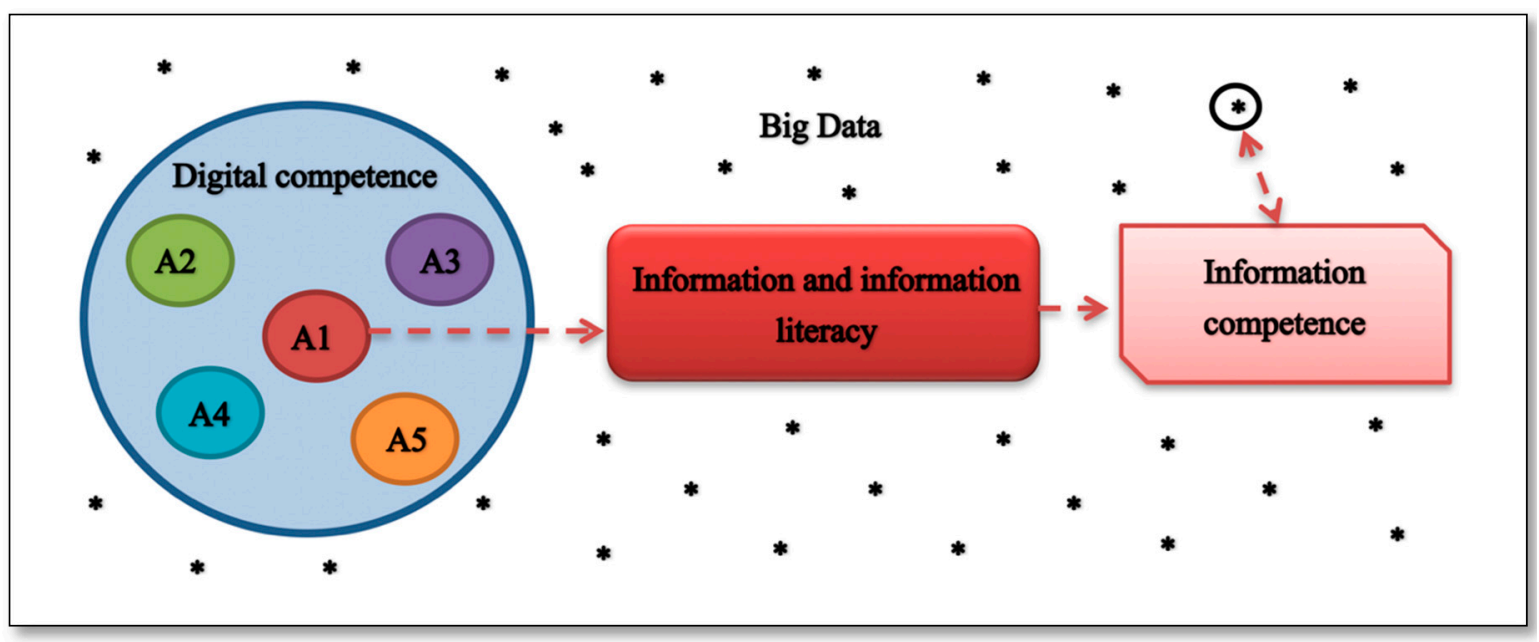

Figure 1. Conceptual relationship of the study.

Therefore, two objectives are set: (1) Know the level of digital competence of teachers in the area of information and information literacy and (2) determine the projection of the Big Data phenomenon in teachers.

For the first objective, the following specific objectives have been formulated:

- Determine the level of skills in each of the dimensions (D) that includes information and information literacy:

- $\quad$ D1: Navigation, search and filtering of information, data and digital content.

- D2: Evaluation of information, data and digital content.

- $\quad$ D3: Storage and retrieval of information, data and digital content.

The second objective has been specified in the following actions:

- Determine the degree of knowledge of teachers regarding the concept of Big Data.

- Specify the level of analytical treatment of teachers in educational Big Data based on the following research questions $(\mathrm{RQ})$ :

- $\quad$ RQ1: Access the data of the discourse interactions in the digital platforms?

- $\quad$ RQ2: Do you use specific programs for your analysis? 
- $\quad$ RQ3: Do you know how to interpret the reported results critically?

- $\quad$ RQ4: Can you transform the data into useful and valuable information to improve the learning process?

- $\quad$ RQ5: Do you make pedagogical decisions based on the information obtained after the analysis and interpretation of the data?

In the same way, it is intended to know if the level of digital competence in the area related to information and information literacy has an impact on the projection of Big Data in teachers.

\section{Materials and Methods}

\subsection{Design and Participants}

In order to achieve the above objectives and to be able to respond to the different questions, a descriptive and correlational research design was defined, based on a quantitative method, taking into consideration the methodological orientations of Hernández, Fernández and Baptista [71].

The study sample was composed of a total of 832 Spanish teachers, of whom $44.6 \%$ were men and $55.4 \%$ were women, with an age between 26 and 61 years (average $=42.37 ; \mathrm{SD}=13.82$ ), who developed their work in primary education $(18.39 \%)$, secondary education $(19.95 \%)$, Bachelor's degree $(20.55 \%)$, professional training $(20.19 \%)$ and higher education (20.91\%). These subjects have been chosen through a stratified random sampling, configuring each stratum according to the educational stages mentioned, with the purpose of obtaining a representative sample of each of them.

\subsection{Instrument}

To collect the data of these participants, an ad hoc questionnaire was used. This instrument has been prepared taking, as references, others already validated in the field of knowledge that this study deals with, such as Agreda, Hinojo and Sola [72], the one generated by INTEF [20] and the one from Touron, Martín, Navarro, Pradas and Inigo [73], which were reported after reviewing the recent scientific literature. The designed questionnaire was composed of 28 questions, classified into five dimensions: 1 -Social (6 items); 2-Navigation, search and filtering (5 items); 3-Evaluation (6 items); 4-Storage and recovery ( 5 items); 5 -Massive data processing ( 6 items). The type of response of each one of the questions is varied, with the majority being Likert-type with a scale of 5 points (from lowest to highest valuation) and others of closed choice.

Once constructed, it was submitted to a process of qualitative validity by the Delphi method to obtain anonymous and objective feedback that would contribute to the improvement of the instrument [74]. The panel of experts was formed by eight specialists in educational technology who were selected based on two criteria: (i) They were a university lecturer and (ii) have conducted studies on ICT applied to education. The feedback granted after the analysis was evaluated from a statistical perspective, using the Fleiss' kappa and Kendall's W tests in order to report indicators of association and agreement between the judgments issued, obtaining relevant values $(\mathrm{K}=0.84 ; \mathrm{W}=0.86)$. Likewise, the reliability of the questionnaire was analyzed, which revealed a high internal consistency (Table 1).

Table 1. Reliability of the questionnaire.

\begin{tabular}{cccc}
\hline Dimension & $\boldsymbol{\alpha}$ & $\mathrm{CR}$ & $\mathrm{EAV}$ \\
\hline Navigation, Search and Filtering & 0.89 & 0.92 & 0.69 \\
Evaluation & 0.87 & 0.90 & 0.76 \\
Storage and Recovery & 0.86 & 0.87 & 0.65 \\
Massive Data Processing & 0.89 & 0.93 & 0.74 \\
\hline
\end{tabular}

Note: $\alpha$ (Cronbach's Alpha); CR (Composite Reliability); EAV (Extracted Average Variance). 


\subsection{Process}

The investigative process began in September 2018 using the telematics in contact with the different educational institutions reported from the database of the Ministry of Education and Vocational Training. Once the subjects were selected by applying the previously specified criteria, the questionnaires were sent in digital format to facilitate their completion. In turn, the data were taken following the ethical principles of anonymity and objective treatment. The data collection phase lasted two months, in which the researchers were available to address any concerns and doubts on the part of the respondents.

\subsection{Data Analysis}

Once the time elapsed, the data was exported and prepared to be introduced to the Statistical Package for the Social Sciences (SPSS) v.22, in which statistics were made such as the average (AV) and standard deviation (SD), the validation and reliability tests of the instrument, as well as the Pearson asymmetry coefficient (PAC) and Fisher's pointing (FPC) to determine the type of distribution. Similarly, the comparison of variables was performed using the Chi-square test of Pearson $\left(\chi^{2}\right)$ and to determine the strength of association between them, the Cramer's V test $(\mathrm{V})$ and the contingency coefficient (Cont) were used. The statistical differences at a significant level were taken based on $p<0.05$.

\section{Results}

This section aims to present the fundamental findings of the investigation, organized in the form of figures and tables for optimal visualization.

First, the results obtained for the analysis of the level of digital competence of teachers in Area 1 (information and information literacy) are reflected in Table 2. The results obtained for the total mean show the level of digital competence of the teachers analyzed in the aforementioned area (average $=3.35)$ taking into account the amplitude established by the five-point Likert table $(\mathrm{R}=4$; $\max =5 ; \min =1)$.

Table 2. Valuations of the teaching competence level in the area of information and literacy.

\begin{tabular}{|c|c|c|c|c|c|c|c|c|c|}
\hline & \multicolumn{5}{|c|}{ Likert Scale $n(\%)$} & \multicolumn{4}{|c|}{ Parameters } \\
\hline & Very Low & Low & Medium & High & Very High & AV & SD & PAC & FPC \\
\hline D1 & $87(10.45)$ & $121(14.54)$ & $207(24.87)$ & $224(26.92)$ & $193(23.19)$ & 3.38 & 1.271 & -0.889 & 1.87 \\
\hline D2 & $94(11.29)$ & $147(17.66)$ & $226(27.15)$ & $214(25.72)$ & $151(18.14)$ & 3.21 & 1.251 & -0.936 & 1.772 \\
\hline D3 & $61(7.33)$ & $130(15.62)$ & $225(27.04)$ & $201(24.15)$ & $215(25.84)$ & 3.45 & 1.231 & -0.884 & 1.993 \\
\hline Total & $242(9.69)$ & $398(15.94)$ & $658(26.36)$ & $639(25.6)$ & $559(22.39)$ & 3.35 & 1.25 & -0.908 & 1.872 \\
\hline
\end{tabular}

Addressing the concrete analysis of each of the dimensions, it was noted that the one related to the storage and retrieval of information, data and digital contents (D3) obtained slightly higher values than the rest, followed by the dimension related to navigation, search and filtering of information, data and digital contents (D1).

Likewise, the dimension that obtained the lowest values within the Likert scale was the one related to the evaluation of information, data and digital contents (D2), even though the differences found are not decisive. We have obtained a general trend of slightly positive asymmetry results, based on the results obtained by the Pearson asymmetry coefficient $(\mathrm{PAC}>0)$ and a platykurtic kurtosis in the analysis of the data concentration in the mean $(\mathrm{FPC}<0)$.

On the other hand, teachers' degree of knowledge about the concept of Big Data has been analyzed in Figure 2. The results reflect a similar distribution at the extremes, with a concentration of frequencies at the midpoint. Thus, there is a significant number of teachers who know the concept Big Data $(75 \%)$, 
regardless of the greater or lesser degree of knowledge and, on the other hand, a smaller sample group $(25 \%)$ that completely ignores the concept of Big Data.

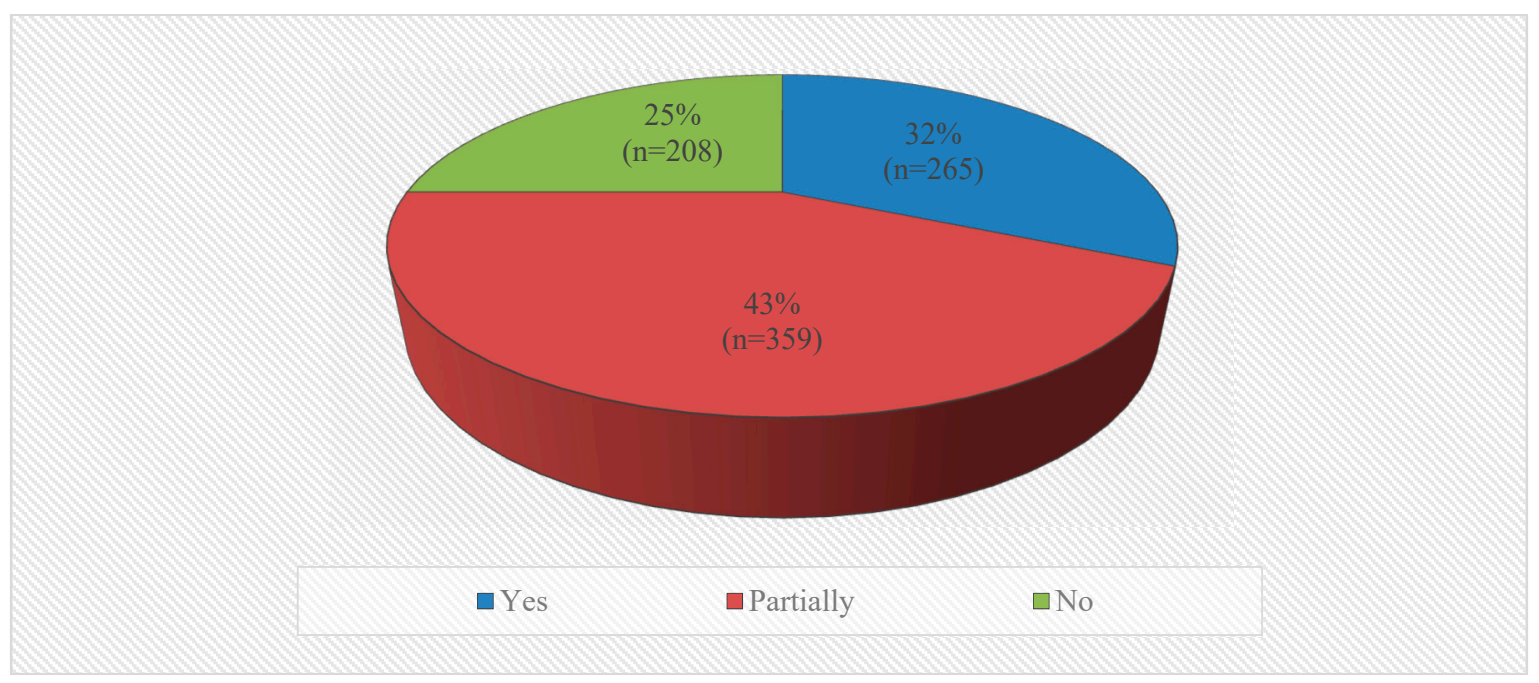

Figure 2. Degree of knowledge of teachers about the concept of Big Data.

Continuing with the analysis of the results, Figure 3 shows the findings regarding the level of the analytical treatment of teachers in terms of educational Big Data. Generally, the teachers access the data of the discourse interactions on the digital platforms with an average assiduity and interpret the reported results critically, even though they do not usually use specific programs to analyze the data. Likewise, we find higher frequency values in those teachers who have referred to an assiduous transformation of the data into useful and valuable information to improve the learning process, and a high predisposition to make methodological decisions based on the information obtained.

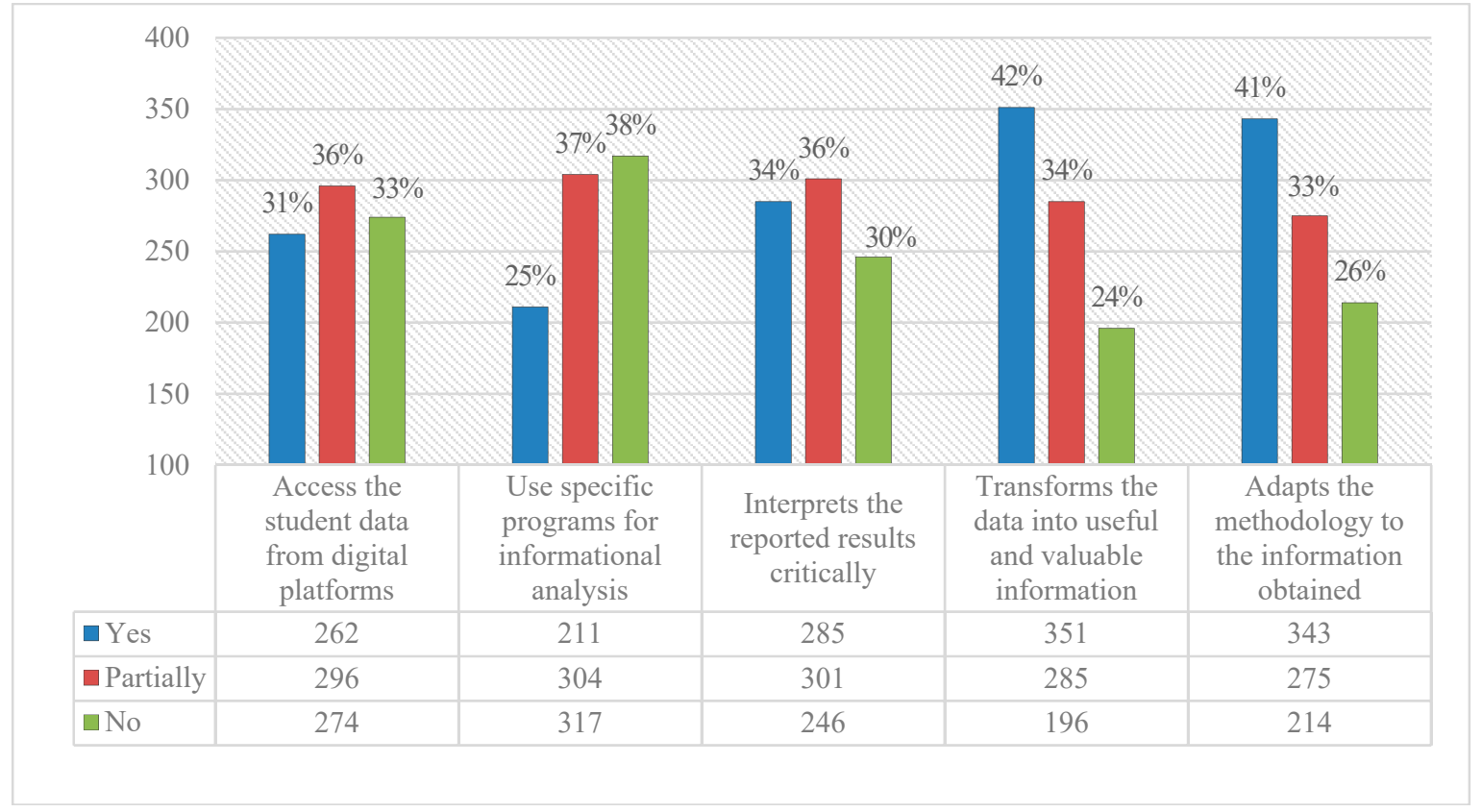

Figure 3. Level of analytical treatment of teachers in educational Big Data.

Finally, Table 3 shows the associative analysis carried out to determine the impact that the level of digital teaching competence in information and digital literacy has on the degree of knowledge of Big Data at the educational level. 
In this way, statistically significant differences have been obtained in the three analyzed dimensions of the first area of digital competence, also showing a strong relationship in each of the mentioned dimensions, as shown by the data obtained in the statistics used to quantify the strength of association (Cramer's V and Pearson's contingency coefficient).

Therefore, those teachers with a higher level of literacy and information in the field of competence have been shown to have greater knowledge than the rest regarding the concept of Big Data. Based on this premise, a directly proportional relationship has been observed between the degree of knowledge in Big data and the level of digital teaching competence in the aforementioned area.

Table 3. Association between the knowledge of big data and the level of digital competence.

\begin{tabular}{|c|c|c|c|c|c|c|c|}
\hline \multirow{2}{*}{ Information and Literacy } & \multicolumn{3}{|c|}{ Knowledge of Big Data $n(\%)$} & \multicolumn{4}{|c|}{ Parameters } \\
\hline & Yes & Partially & No & $\chi^{2}(d f)$ & $p$ Value & Cont & $\mathbf{V}$ \\
\hline D1: Browse search and filter & & & & $116.6(8)$ & $<0.001$ & 0.351 & 0.530 \\
\hline Very low & $17(2.04)$ & $28(3.36)$ & $42(5.04)$ & & & & \\
\hline Low & $24(2.88)$ & $55(6.61)$ & $42(5.04)$ & & & & \\
\hline Medium & $44(5.28)$ & $87(10.45)$ & $76(9.13)$ & & & & \\
\hline High & $85(10.21)$ & 97 (11.65) & $42(5.04)$ & & & & \\
\hline Very High & $95(11.41)$ & $92(11.05)$ & $6(0.72)$ & & & & \\
\hline D2: Evaluate & & & & $239.7(8)$ & $<0.001$ & 0.473 & 0.759 \\
\hline Very low & $11(1.32)$ & $21(2.52)$ & $62(7.45)$ & & & & \\
\hline Low & $25(3.01)$ & $48(5.76)$ & $74(89.89)$ & & & & \\
\hline Medium & $56(6.73)$ & 132 (15.8) & $38(4.56)$ & & & & \\
\hline High & $84(10.09)$ & $98(11.77)$ & $32(3.84)$ & & & & \\
\hline Very High & 89 (10.69) & $60(7.21)$ & $2(0.24)$ & & & & \\
\hline D3: Store and recover & & & & $238.5(8)$ & $<0.001$ & 0.472 & 0.757 \\
\hline Very low & $5(0.61)$ & $16(1.921)$ & $40(4.81)$ & & & & \\
\hline Low & $22(2.64)$ & 63 (7.57) & 45 (5.41) & & & & \\
\hline Medium & $32(3.84)$ & $104(12.5)$ & 89 (10.69) & & & & \\
\hline High & $70(8.41)$ & 107 (12.9) & $24(2.88)$ & & & & \\
\hline Very High & $136(16.3)$ & $69(8.29)$ & $10(1.2)$ & & & & \\
\hline
\end{tabular}

\section{Discussion}

As has been exposed in previous studies, digital competence has become one of the most relevant professional competencies of teachers in contemporary education $[35,36]$, due to the large influence of educational technology in the different learning spaces that can be generated today $[1,14,39]$. These teachings can be generated both physically and virtually [2] through content management platforms that not only offer a digital site to store the information but also become spaces for interaction $[44,45]$, with students having the ability to communicate and collaborate with their peers and with teachers to carry out tasks, as well as being able to carry out the construction of ubiquitous knowledge [37].

These platforms, and the proliferation of educational resources and applications, have generated a huge amount of data $[46,47]$. Therefore, teachers have a powerful tool to understand the needs and demands of the students with analysis of the Big Data generated by the actions of the students in their daily activities [54].

Despite this, to take advantage of the potential of Big Data in education, it is essential to have informational competencies, alluding to Area 1 of the digital teaching competence $[60,63]$, in order to have skills to locate, access, analyze and interpret the data $[64,65,67]$. With the necessary skills, it is possible to generate new, valuable and useful information that facilitates critical decision-making [66] and has an impact on effective strategic action by teachers, thereby improving the quality of teaching and learning processes [58]. In all of this, digital competence plays a fundamental role, making it 
essential for all teachers to have an adequate level to perform analytical practices using large volumes of data, especially in the area of information and information literacy, in its three dimensions.

\section{Conclusions}

In this study, teachers were found to have a medium level of digital competence regarding the informational area. This finding is consistent with other previous research, which reveals a lack of competence in that area $[68,69]$. Likewise, in order to specify the results and seek a differentiating nuance with previous studies, each of the three dimensions that make up Area 1 of the digital teaching competence have been analyzed. In this analysis, it was found that the dimension corresponding to the storage and retrieval of information, data and digital content has reached a level of competency superior to that of the other dimensions, followed by the skills in navigation, search and filtering of information, data and digital content and culminating with the dimension related to the evaluation of these, which has reflected deficient values.

It is pertinent to highlight that the concept of digital competence has been addressed by the scientific community from different perspectives, depending on the level of geographical concretion. For example, in Europe, the convergence of the European Framework of Digital Competencies for Citizens (DigComp) and the European Framework for the Digital Competence of Teachers (DigCompEdu) is among the most prominent. However, due to the context of this study, the digital competence established by the competent body in the Spanish state, the National Institute of Educational Technologies and Teacher Training [20], is considered as a reference.

Similarly, we have investigated the knowledge that teachers possess in reference to the Big Data term, confirming that three out of four teachers are aware of this concept. Regarding its treatment and analysis, the results reveal that, on average, they access the educational data generated by the content management platforms and interpret the reported data in a critical manner, all without using mass analysis software. In addition, many of the respondents stated that they convert data into relevant information, allowing decisions to be made that entail a methodological readjustment in order to improve the training process.

Regarding whether the level of informational competence affects the level of knowledge about Big Data in educational matters, the tests carried out have postulated statistical significance, showing that teachers with greater skills in Area 1 of digital competence have better knowledge about this concept, showing a directly proportional link. These results allow us to respond both to the objectives set and to the questions formulated in the present study.

These findings lead to a reflection on the question in the teaching group that is currently teaching at different stages of education. There is no doubt that education is in full evolution and is increasingly adjusting to the characteristics of a digital society. Therefore, teachers must demonstrate a level of digital competence appropriate to the demands of new teaching and learning environments, which report a large amount of data that can effectively address the needs of many students, to flexibilize and individualize the formative processes. This can be achieved thanks to the analytical study of Big Data produced by educational technology.

However, the prospective that emerges from this research should not only be extended to the continuous training of teachers to acquire and improve their digital competence levels, but also should be considered in the university training plans, with the view that the new generations of teachers have assimilated the skills, abilities and knowledge necessary to carry out an effective management of Big Data from their initial training period.

The main limitation of the study focuses on the non-distinction in the results among the teachers of the different educational stages regarding the state of the issue dealt with in this work, since there was no differentiation between the higher education faculty and the rest of the teaching professionals. As a future line of research, the limitation of the study should be taken into consideration, in addition to analyzing both the level of informational competencies and the projection of Big Data in future teachers of Spanish universities, with the intention of ascertaining if the future educational professionals are 
qualified to make effective use of the large volume of educational data that are generated in virtual learning spaces every day.

Author Contributions: All authors have contributed in the elaboration of the manuscript.

Funding: This research received no external funding.

Conflicts of Interest: The authors declare no conflict of interest.

\section{References}

1. Rodríguez, A.M.; Cáceres, M.P.; Alonso, S. La competencia digital del futuro docente: Análisis bibliométrico de la productividad científica indexada en Scopus. Ijeri 2018, 10, 317-333.

2. Arzola, D.; Loya, C.; González, A. El trabajo directivo en educación primaria: Liderazgo, procesos participativos y democracia escolar. IE De La REDIECH 2017, 7, 35-41.

3. Area, M. La alfabetización digital y la formación de la ciudadanía del siglo XXI. Rev. Integr. Educ. 2015, 7, 21-33.

4. Viñals, A.; Cuenca, J. El rol del docente en la era digital. RIFOP 2016, 30, 103-114.

5. Jiménez, D.; Sancho, P.; Sánchez, S. Perfil del futuro docente: Nuevos retos en el marco de EEES. Contextos Educ. 2019, 23, 125-139. [CrossRef]

6. Organic Law 8/2013, of December 9th, for the Improvement of Educational Quality. State Official Newsletter, 10 December 2013; 1-64.

7. Area, M.; Hernández, V.; Sosa, J.J. Modelos de integración didáctica de las TIC en el aula. Comunicar 2016, 24, 79-87. [CrossRef]

8. Cabero, J.; Barroso, J. Los escenarios tecnológicos en Realidad Aumentada (RA): Posibilidades educativas en estudios universitarios. RIFIE 2018, 47, 327-336. [CrossRef]

9. Murillo, F.J.; Krichesky, G.J. Mejora de la Escuela: Medio siglo de lecciones aprendidas. REICE 2015, 13, 69-102.

10. Maquilón, J.J.; Mirete, A.B.; Avilés, M. La Realidad Aumentada (RA). Recursos y propuestas para la innovación educativa. RIFOP 2017, 20, 183-204.

11. Mingorance, A.C.; Trujillo, J.M.; Cáceres, M.P.; Torres, C. Mejora del rendimiento académico a través de la metodología de aula invertida centrada en el aprendizaje activo del estudiante universitario deficiencias de la educación. JSHR 2017, 9, 129-136.

12. Medellín, M.L.; Gómez, J.A. Uso de las TIC como estrategia de mediación para el aprendizaje de la lectura en educación primaria. Gestión Compet. Innov. 2018, 6, 12-21.

13. Laskaris, D.; Kalogiannakis, M.; Heretakis, E. Interactive evaluation of an e-learning course within the context of blended education. IJTEL 2017, 9, 339-353. [CrossRef]

14. Kumar, A.; Kumar, G. The Role of ICT in Higher Education for the 21st Century: ICT as A Change Agent for Education. Multidiscip. High. Educ. Res. Dyn. Concepts Oppor. Chall. For. Sustain. Dev. 2018, 1, 76-83.

15. Moreno, N.; López, E.; Leiva, J. El uso de tecnologías emergentes como recursos didácticos en ámbitos educativos. Int. Stud. Law Educ. 2018, 29, 131-146.

16. Aznar, I.; Cáceres, M.P.; Trujillo, J.M.; Romero, J.M. Impacto de las apps móviles en la actividad física: Un meta-análisis. Retos 2019, 36, 52-57.

17. Castañeda, L.; Esteve, F.; Adell, J. ¿Por qué es necesario repensar la competencia docente para el mundo digital? RED 2018, 56, 1-20. [CrossRef] [PubMed]

18. Lázaro, J.L.; Gisbert, M.; Silva, J.E. Una rúbrica para evaluar la competencia digital del profesor universitario en el contexto latinoamericano. EDUTEC 2018, 63, 1-14. [CrossRef]

19. Avitia, P.; Uriarte, I. Evaluación de la habilidad digital de los estudiantes universitarios: Estado de ingreso y potencial educativo. EDUTEC 2017, 61, 1-13.

20. INTEF. Marco de Competencia Digital; Ministerio de Educación, Ciencia y Deportes: Madrid, Spain, 2017.

21. Fernández, F.J.; Fernández, M.J.; Rodríguez, J.M. El proceso de integración y uso pedagógico de las TIC en los centros educativos madrileños. Educ. XX1 2018, 21,395-416. [CrossRef]

22. Fernández, J.M.; Rodríguez, A. TIC y diversidad funcional: Conocimiento del profesorado. EJIHPE 2017, 7, 157-175. [CrossRef] 
23. Fuentes, A.; López, J.; Pozo, S. Análisis de la competencia digital docente: Factor clave en el desempeño de pedagogías activas con Realidad Aumentada. REICE 2019, 17, 27-42. [CrossRef]

24. Cela, J.M.; Esteve-González, V.; Esteve-Mon, F.; González, J.; Gisbert, M. El docente en la sociedad digital: Una propuesta basada en la pedagogía transformativa y en la tecnología avanzada. Profesorado 2017, 21, 403-422.

25. Pérez, A.; Rodríguez, M. Evaluación de las competencias digitales autopercibidas del profesorado de Educación Primaria en Castilla y León (España). RIE 2016, 34, 399-415. [CrossRef]

26. Padilla, S. Usos y actitudes de los formadores de docentes ante las TIC. Entre lo recomendable y la realidad de las aulas. Apertura 2018, 10, 132-148. [CrossRef]

27. Prendes, M.P.; Gutiérrez, I.; Martínez, F. Competencia digital: Una necesidad del profesorado universitario en el siglo XXI. RED 2018, 56, 1-22. [CrossRef]

28. Sorroza, N.A.; Jinez, J.P.; Rodríguez, J.E.; Caraguay, W.A.; Sotomayor, M.V. Las Tic y la resistencia al cambio en la Educación Superior. RECIMUNDO 2018, 2, 477-495.

29. Morán, R.; Cardoso, E.O.; Cerecedo, M.T.; Ortíz, J.C. Evaluación de las Competencias Docentes de Profesores Formados en Instituciones de Educación Superior: El Caso de la Asignatura de Tecnología en la Enseñanza Secundaria. Form. Univ. 2015, 8, 57-64. [CrossRef]

30. Afanador, H.A. Estado actual de las competencias TIC de docentes. Puente 2017, 9, $23-32$.

31. Falcó, J.M. Evaluación de la competencia digital docente en la Comunidad Autónoma de Aragón. REDIE 2017, 19, 73-83. [CrossRef]

32. Fernández, F.J.; Fernández, M.J. Los docentes de la Generación Z y sus competencias digitales. Comunicar 2016, 24, 97-105.

33. Fernández, E.; Leiva, J.J.; López, E. Competencias digitales en docentes de Educación Superior. RIDU 2018, 12, 213-231. [CrossRef]

34. Manso, J.; Ezquerra, Á.; Burgos, M.E.; Mafokozi, J. Análisis del tratamiento de contenidos en la creación de audiovisuales educativos. REurEDC 2019, 16, 1-16. [CrossRef]

35. López, M.; Bernal, C. El perfil del profesorado en la Sociedad Red: Reflexiones sobre las competencias digitales de los y las estudiantes en Educación de la Universidad de Cádiz. Ijeri 2019, 11, 83-100.

36. Cabero, J.; Ruiz, J. Las Tecnologías de la Información y Comunicación para la inclusión: Reformulando la brecha digital. IJERI 2018, 9, 16-30.

37. Rodríguez, A.M.; Martínez, N.; Raso, F. La formación del profesorado en competencia digital: Clave para la educación del siglo XXI. REIDOE 2017, 3, 46-65.

38. Hinojo, F.J.; Aznar, I.; Romero, J.M. Dispositivos móviles para el aprendizaje: Análisis de la investigación doctoral sobre mobile learning en España. Texto Livre 2018, 11, 154-175. [CrossRef]

39. Fombona, J.; Pascual, M.A.; González, M. M-learning y realidad aumentada: Revisión de literatura científica en el repositorio WoS. Comunicar 2017, 25, 63-72. [CrossRef]

40. Kumar, B.A.; Mohite, P. Usability of mobile learning applications: A systematic literature review. JCE 2018, 5, 1-17. [CrossRef]

41. Crompton, H.; Burke, D. The use of mobile learning in higher education: A systematic review. Comput. Educ. 2018, 123, 53-64. [CrossRef]

42. Kearney, M.; Maher, D. Mobile learning in pre-service teacher education: Examining the use of professional learning networks. AJET 2019, 35, 135-148. [CrossRef]

43. Pargman, T.C.; Nouri, J.; Milrad, M. Taking an instrumental genesis lens: New insights into collaborative mobile learning. BJET 2018, 49, 219-234. [CrossRef]

44. Brazuelo, F.; Gallego, D. Estado del Mobile Learning en España. Educ. Em Rev. 2014, 4, 99-128.

45. Ramírez, M.; García, F. La integración efectiva del dispositivo móvil en la educación y en el aprendizaje. RIED 2017, 20, 29-47. [CrossRef]

46. Elia, G.; Solazzo, G.; Lorenzo, G.; Passiante, G. Assessing learners' satisfaction in collaborative online courses through a big data approach. Comput. Hum. Behav. 2019, 92, 589-599. [CrossRef]

47. Zheng, Y.; Wang, J.; Doll, W.; Deng, X.; Williams, M. The impact of organisational support, technical support, and self-efficacy on faculty perceived benefits of using learning management system. BIT 2018, 37, 311-319. [CrossRef] 
48. Waller, M.A.; Fawcett, S.E. Data Science, Predictive Analytics, and Big Data: A Revolution That Will Transform Supply Chain Design and Management. JBL 2013, 34, 77-84. [CrossRef]

49. Ghani, N.A.; Hamid, S.; Targio, I.A.; Ahmed, E. Social media big data analytics: A survey. Comput. Hum. Behav. 2018, 1-12, in press. [CrossRef]

50. Pugna, I.B.; Duțescu, A.; Stanila, O.G. Corporate Attitudes towards Big Data and Its Impact on Performance Management: A Qualitative Study. Sustainability 2019, 11, 684. [CrossRef]

51. Veltri, G.A. Big Data is not only about data: The two cultures of modelling. BDES 2017, 4. [CrossRef]

52. Hussain, A.; Cambria, E. Semi-supervised learning for big social data analysis. Neurocomputing 2018, 275, 1662-1673. [CrossRef]

53. Hicks, S.C.; Irizarry, R.A. A guide to teaching data science. Am. Stat. 2018, 72, 382-391. [CrossRef] [PubMed]

54. Perlado, M.; Papí, N.; Bergaz, M. Del planificador de medios al experto en medios: El efecto digital de la publicidad. Comunicar 2019, 27, 105-114. [CrossRef]

55. Moreno-Carriles, R.M. Big data, ¿pero qué es? Angiología 2018, 70, 191-194. [CrossRef]

56. García-Aretio, L. Educación a distancia y virtual: Calidad, disrupción, aprendizajes adaptativo y móvil. RIED 2017, 20, 9-25. [CrossRef]

57. Gibson, D. Big data in higher education: Research methods and analytics supporting the learning journey. Technol. Knowl. Learn. 2017, 22, 237-241. [CrossRef]

58. Liang, J.; Yang, J.; Wu, Y.; Li, C.; Zheng, L. Big data application in education: Dropout prediction in edx MOOCs. In Proceedings of the IEEE Second International Conference on Multimedia Big Data, Taipei, Taiwan, 20-22 April 2016.

59. Merceron, A.; Blikstein, P.; Siemens, G. Learning analytics: From big data to meaningful data. JLA 2015, 2, 4-8. [CrossRef]

60. Huda, M.; Maseleno, A.; Atmotiyoso, P.; Siregar, M.; Ahmad, R.; Jasmi, K.; Jasmi, K.A.; Nor, N.H. Big data emerging technology: Insights into innovative environment for online learning resources. iJET 2018, 13, 23-36. [CrossRef]

61. Reidenberg, J.R.; Schaub, F. Achieving big data privacy in education. Theory Res. Educ. 2018, 16, $263-279$. [CrossRef]

62. Huda, M.; Maseleno, A.; Shahrill, M.; Jasmi, K.A.; Mustari, I.; Basiron, B. Exploring adaptive teaching competencies in big data era. iJET 2017, 12, 68-83. [CrossRef]

63. Bielba, M.; Martínez, F.; Rodríguez, M.J. Validación psicométrica de un instrumento de evaluación de competencias informacionales en la educación secundaria. Bordón 2017, 69, 27-43. [CrossRef]

64. Beltrán, J.A.; Ramírez, M.O.; García, R.I. Propiedades métricas de un instrumento de autoreporte para medir la competencia informacional de maestros de primaria. Pixel-bit 2017, 50, 147-158. [CrossRef]

65. Gallardo, I.L.; Lau, J. La alfabetización informacional en docentes de educación básica. RETE Número Espec. Educ. Med. Tecnol. Altern. Digit. Virtuales 2016, 1, 190-211.

66. García-Llorente, H.J. Multialfabetización en la sociedad del conocimiento: Competencias informacionales en el sistema educativo. Rev. Lasallista Investig. 2015, 12, 225-241. [CrossRef]

67. Valverde, D.; Pro, A.J.; González, J. La competencia informacional-digital en la enseñanza y aprendizaje de las ciencias en la educación secundaria obligatoria actual: Una revisión teórica. REurEDC 2018, 15, 1-15. [CrossRef]

68. Menon, A.; Gaglani, S.; Haynes, M.R.; Tackett, S. Using “big data” to guide implementation of a web and mobile adaptive learning platform for medical students. Med Teach. 2017, 39, 975-980. [CrossRef] [PubMed]

69. Álvarez, J.F.; Gisbert, M. Grado de alfabetización informacional del profesorado de Secundaria en España: Creencias y autopercepciones. Comun. Rev. Cientifica Iberoam. Comun. Educ. 2015, 45, 187-194. [CrossRef]

70. Dishon, G. New data, old tensions: Big data, personalized learning, and the challenges of progressive education. Theory Res. Educ. 2017, 15, 272-289. [CrossRef]

71. Hernández, R.; Fernández, C.; Baptista, M.P. Metodología de la Investigación; McGraw Hill: Madrid, Spain, 2014.

72. Agreda, M.; Hinojo, M.A.; Sola, J.M. Diseño y validación de un instrumento para evaluar la competencia digital de los docentes en la Educación Superior española. Pixel-Bit 2016, 49, 39-56. [CrossRef]

73. Tourón, J.; Martín, D.; Navarro, E.; Pradas, S.; Íñigo, V. Validación de constructo de un instrumento para medir la competencia digital docente de los profesores (CDD). REP 2018, 269, 25-54. [CrossRef] 
74. Cabero, J.; Infante, A. Empleo del método Delphi y su empleo en la investigación en comunicación y educación. EDUTEC 2014, 48, a272.

(). (1)

(C) 2019 by the authors. Licensee MDPI, Basel, Switzerland. This article is an open access article distributed under the terms and conditions of the Creative Commons Attribution (CC BY) license (http://creativecommons.org/licenses/by/4.0/). 